\title{
Crystallographic and Magnetic Properties of $\mathrm{Al}^{3+}$ co-doped $\mathrm{NiZnFe}_{2} \mathrm{O}_{4}$ Nano-particles Prepared by Sol-gel Process
}

\author{
Amany M. El Nahrawy¹, Heba Salah El-Deen², Aisha A. Soliman³, Wafaa M.M. \\ Mosa $^{4}$ \\ ${ }^{1}$ Solid State Physics Department, Physics Research Division, National Research Centre \\ (NRC)-33 El Bohouth st, P.O.12622, Dokki, Giza, Egypt. (Affiliation ID:60014618) \\ ${ }^{2}$ Department of Physics and Chemistry, Faculty of Women for Arts, Science and \\ Education, Ain Shams University, Cairo, Egypt. \\ ${ }^{3}$ Department of Solid State Physics, Faculty of Women for Arts, Science and Education, \\ Ain Shams University, Cairo, Egypt. \\ ${ }^{4}$ Department of Spectrum Physics, Faculty of Women for Arts, Science and Education, \\ Ain Shams University, Cairo, Egypt.
}

\begin{abstract}
A $\mathrm{l}_{2} \mathrm{O}_{3}$ SUBSTITUTED nickel zinc nano-ferrite $\mathrm{Al}_{\mathrm{x}} \mathrm{Ni}_{0.5-\mathrm{x}} \mathrm{Zn}_{0.5} \mathrm{Fe}_{2} \mathrm{O}_{4}(\mathrm{x}=0.0,0.1,0.2$, 0.3 ) was prepared by the citrate sol-gel methodusing nickel, zinc, iron and aluminum nitratesand sintered at $800^{\circ} \mathrm{C}$ for $3 \mathrm{~h}$ in air. Prepared nano-sized ferrites were characterized by $\mathrm{X}$-ray diffraction, High resolution transmission and scanning electron microscopy and Fourier transforms infrared spectroscopy. The estimated crystallite sizes were in the range of $24.7-$ $32.9 \mathrm{~nm}$. HR-TEM data appears that all nano-ferrite samples are composed of more or less agglomerated nanoparticles with the average particle size of nanocrystallites is $\sim 31 \mathrm{~nm}$. The impact of introducing $\mathrm{Al}$ ions by $\mathrm{Ni}$ on themagnetic properties of the prepared nano-ferrite was investigated utilizing magnetic measurements at room temperature. The changing of crystallite sizes, lattice parameter and the surface area with increasing the Al content were determined. The saturation magnetization (Ms) and coercivity (Hc) values vary from 47.894-32.314 and 70.37-60.117 G; respectively.
\end{abstract}

Keywords: Nano-crystalline ferrites, Nickel zinc ferrite, Sol-gel process, Spinel ferrite, Magnetic properties.

\section{Introduction}

Recently, soft ferrites are most versatile due to their technological applications, especially prepared by chemical methods [1]. Chemical methods as sol gel process provide high purity and homogeneity, uniform distribution of dopants ions at the molecular level and high efficiency [2]. Ni-Zn ferrites are known and have been applied in various the electrical and electronic industries, due to their interesting electrical and magnetic properties $[3,4]$. Nickel zinc ferrites as spinel-type structures, have a particular interest from the researchers much due to its using in various industrial electronic applications, such as communication devices (mobile phones), drug delivery, TVs, sensors, data storage, radios, microwaves,... etc. [4-6].The spinel structure name is offered due to its structure arrangement in which metal ions are distributed between (A site) tetrahedral and (B site) octahedral sites formed through the oxygen ions in a unit cell $[7,8]$. So, the distribution of metal ions through the $\mathrm{A}$ site and $\mathrm{B}$ site affects the magnetic properties of $\mathrm{M}-\mathrm{Fe}_{2} \mathrm{O}_{4}$, which may be controlled by thermal treatment and crystallite size [9]. Nickel zinc ferrite belongs to the soft magnetic materials group, which is easily magnetized and demagnetized. Most electronic and magnetic applications require polycrystalline ferrite materials to be pressed into larger shapes, which is difficult to produce if the particles have wide-size distribution $[10,11]$. The variation in the starting composition of $\mathrm{Ni}-\mathrm{Zn}$-ferrite results in the rearrangement of metal ions through $\mathrm{A}$ and $\mathrm{B}$ sites, which can modify the properties of these ferrites. Thus, more investigations are still required to be done to produce $\mathrm{Ni}-\mathrm{Zn}$ ferrite with narrow grain size distribution, high surface and controlled porosity leading to better structural, magnetic and electrical properties $[12,13]$. The

*Corresponding author e-mail: amany_physics_1980@yahoo.com

DOI: 10.21608/EJCHEM.2018.4504.1397

C2019 National Information and Documentation Center (NIDOC) 
properties of ferrite materials change as their nanoscale size and as the level of atoms at the surface of a material become important. The superior properties of ferrites nanoparticles are therefore largely due to the large fraction of atoms that occupies the grain boundary area [14]. The synthesis of new magnetic systems, such as ironbased, led the modification of metallic materials with a nano-crystalline structure and non-classical properties. The production process progression in the size control and characterization of these magnetic systems has entailed to numerous benefits, both in the scientific and technological fields $[14,15]$. Considerable interest in chemical methods for the synthesis of nano-ferrite nanoparticles has been controled to explore better materials with controllable shape, nano-scale, and stability for multi-applications sol-gel methods $[15,16]$.

The sol-gel method as a one of the low temperature chemical methods was used for synthesis ferrites nano materials, which allows to introduce different modifiers such as $\mathrm{Zn}, \mathrm{Al}$, $\mathrm{Ce}$ and $\mathrm{Cu}$ ions in the ferrite materials could also enhance their structural and magnetic properties [15-17].

The main idea behind using the sol-gel process is to "dissolve" the compounds in a liquid in order to bring it back as a solid in a controlled manner at nano-scale.In this study, according to the importance of $\mathrm{Al}_{2} \mathrm{O}_{3}$ - nanoferrites, this attempt has been made to study the effect of substitution $\mathrm{Ni}$ ions by $\mathrm{Al}_{2} \mathrm{O}_{3}$ ions on the structural and magnetic properties of $\mathrm{Al}_{\mathrm{x}} \mathrm{Ni}_{0.5-\mathrm{x}} \mathrm{Zn}_{0.5} \mathrm{Fe}_{2} \mathrm{O}_{4}$ nanocrystalline. The nano-magnetic samples with the composition $\mathrm{Al}_{\mathrm{x}} \mathrm{Ni}_{0.5-\mathrm{x}} \mathrm{Zn}_{0.5} \mathrm{Fe}_{2} \mathrm{O}_{4}(\mathrm{x}=0.0,0.2$, $0.5,0.8)$ were prepared via citrate sol gel method and calcined at $800^{\circ} \mathrm{C}$ for $3 \mathrm{~h}$ in air. This method involves the hydrolysis and poly-condensation reactions of the nickel, zinc, iron and aluminum nitrates, in aqueous citrate acid producing xerogel at $100^{\circ} \mathrm{C}$. The structural and magnetic behavior of these samples was studied. The produced nanoferrite was characterized by X-ray diffraction (XRD), high resolution transmission and scanningelectron microscopy (HRTEM/SEM), Fourier Transforms Infrared (FTIR) and vibrating sample magnetometer (VSM) techniques.

\section{Experimental}

$\mathrm{Al}_{\mathrm{x}} \mathrm{Ni}_{0.5-\mathrm{x}} \mathrm{Zn}_{0.5} \quad \mathrm{Fe}_{2} \mathrm{O}_{4}$ nano-crystalline was prepared using citrate sol gel method at room temperature. Nickel, zinc, aluminum nitrates and ferrous nitrates were used as starting materials. The preparation process was carried out at room temperature, in which distilled water $\left(\mathrm{H}_{2} \mathrm{O}\right)$ was taken and nitrates of nickel (Ni), zinc ( $\mathrm{Zn})$, aluminum (Al) and iron as starting materials were added in stoichiometry proportion to the water. The citric acid was added drop by drop on the mixture and stirring for $2 \mathrm{~h}$ and dried at $100^{\circ} \mathrm{C}$ until all solvents were continuously dried to obtain uniform gel and produce the precipitate. The previous stapes were repeated with different concentration of $(\mathrm{x}=0.0,0.2,0.5,0.8) \mathrm{Al}_{2} \mathrm{O}_{3}$ ions. The obtained brownish powder was calcined at $800^{\circ} \mathrm{C}$ for $3 \mathrm{~h}$ in a muffle furnace with heating rate $5^{\circ} \mathrm{C} / \mathrm{min}$ in air. X-ray diffraction (XRD) patterns of the prepared sample were recorded with an X-ray diffractometer using monochromatized $\mathrm{CuK} \alpha 1$ radiation of wavelength $=1.54056 \AA$. Crystallite sizes $G$ were determined from the Scherer's equation $(\mathrm{G}=\mathrm{K} \lambda / \mathrm{D} \cos \theta)$, where $\mathrm{K}$ is the Scherer constant (0.9), $\lambda$ : is the wavelength, and $\mathrm{D}$ is the full width (in radians) of the peak at half maximum (FWHM) intensity. The morphological features were studied using JEOL (JEM-2100) transmission electron microscope (HRTEM) and high resolution scanning electron microscope (HRSEM). Fourier Transforms Infrared, were used to determine the individual frequencies and their intensities, in the range of $400 \mathrm{~cm}^{-1}$ to $4000 \mathrm{~cm}^{-1}$, using the $\mathrm{KBr}$ pellet method. The magnetic properties were measured using a vibrating sample magnetometer (VSM Model Lakeshore).

\section{$\underline{\text { Results and Discussion }}$}

X-Ray Diffraction (XRD) Studies:

Figure 1 represents the XRD pattern of $\mathrm{Ni}_{0.5}$ $\mathrm{Zn}_{0.5} \mathrm{Fe}_{2} \mathrm{O}_{4}$ doped with different concentrations of $\mathrm{Al}_{2} \mathrm{O}_{3}$ ions $(0.1,0.2 \& 0.3)$ after calcination at $800^{\circ} \mathrm{C}$, to analyze the formation of the crystalline phases. All the prepared samples show characteristic peaks assigned to the homogeneous cubic spinel structure (JCPDS No.08-0234) with a lattice parameter changes from $8.42 \mathrm{~A}^{\circ}$ to 8.63 $\mathrm{A}^{\circ}$ with introducing Alions and corresponding planes of (111), (220), (311), (222), (400), (422), (511), (531), (620), (533) and (444), representing the ferrite lattice $[18,19]$.From the figures the sharpness and broadening of Bragg's peaks indicate the good and complete formation of pure and doped $\mathrm{Ni}_{0.5} \mathrm{Zn}_{0.5} \mathrm{Fe}_{2} \mathrm{O}_{4}$ using the citrate sol gel process. The Lattice constant, X-Ray density and the induced strain is calculated from the Williamson-Hall method [20], as shown in Table 
1. There is a small shifting of the diffraction peak towards higher (2 $\theta)$; this may be due to replacement of Niby Alions as shown in Fig. 1. The average crystallite size of the prepared nano-ferrite samples (D) is determined from the broadening of the high intensity peak (311) using the Debye -Scherrer's equation [20]. The crystallite size increases from $24.67 \mathrm{~nm}$ for the $\mathrm{Ni}_{0.5} \mathrm{Zn}_{0.5} \mathrm{Fe}_{2} \mathrm{O}_{4}$ to $30.85 \mathrm{~nm}$ with increasing $\mathrm{Al}_{2} \mathrm{O}_{3}$ content. This means that the crystallite sizes are increased due to the decrease in the induced strain as shown in Table 1. The observed broadening of XRD pattern for doped nickel zinc ferrite nanocrystalline is ascribed to the crystallite size-induced or strain induced broadening. From the table it is note that the experimental lattice parameter and density decreases with increasing $\mathrm{Al}$ content in the spinel structure $\mathrm{Al}_{\mathrm{x}} \mathrm{Ni}_{0.5-\mathrm{x}} \mathrm{Zn}_{0.5} \mathrm{Fe}_{2} \mathrm{O}_{4}$. This can be attributed to the change of the relative ionic radii of $\mathrm{Ni}^{2+}, \mathrm{Al}^{2+}$, and $\mathrm{Fe}^{3+}$ ions where $\mathrm{Ni}^{2+}$ ions have greater ionic radii $\left(0.69 \mathrm{~A}^{\circ}\right)$, than $\mathrm{Al}^{2+}$ ions $(0.67$ $\left.\mathrm{A}^{\circ}\right)$ in the octahedral sites [21]. So, the partial substitution of the $\mathrm{Ni}$ ions by the $\mathrm{Al}$ ions causes little shrinkage of unit cell dimensions, thereby decreasing the lattice parameter, as shown below in Table 1.

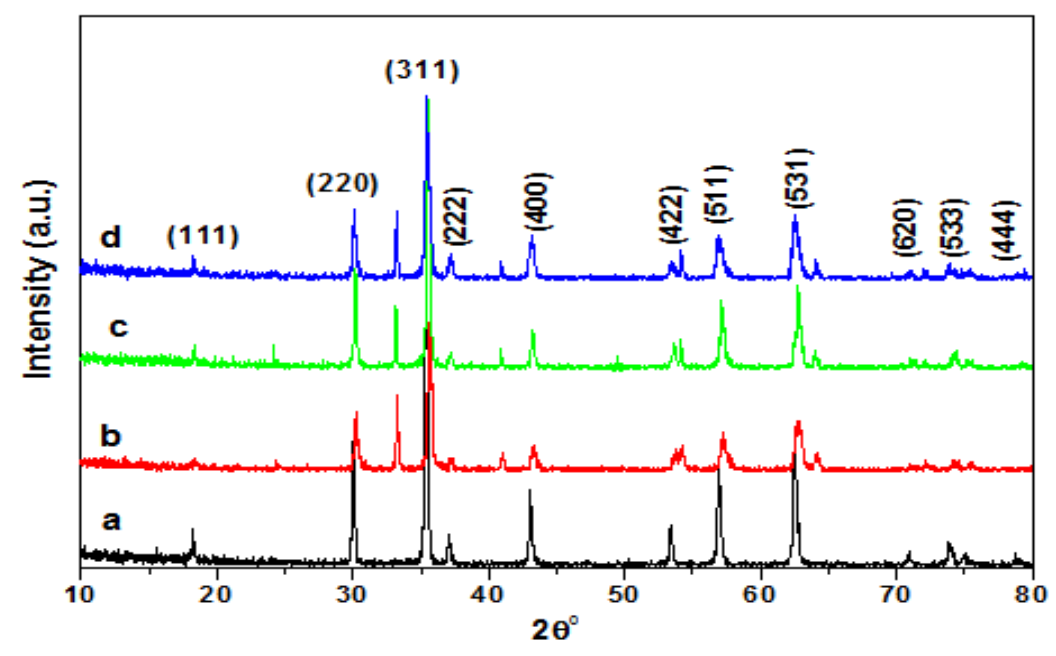

Fig. 1. X-ray diffraction patterns of Alx Ni 0.5- $x \mathrm{Zn0.5Fe}_{2} \mathrm{O}_{4}(x=0.0,0.1,0.2 \& 0.3)$ nano-crystalline calcined at $800^{\circ} \mathrm{C}$ for $3 \mathrm{~h}$.

TABLE 1. Variation of crystallite size, Lattice constant, D-spacing and X-Ray density with $\mathrm{Ni}_{\mathrm{x}} \mathrm{Zn}_{1-\mathrm{x}} \mathrm{Fe}_{2} \mathrm{O}_{4}$ doped with $\mathrm{Al}_{2} \mathrm{O}_{3}(x=0.0,0.1,0.2 \& 0.3)$.

\begin{tabular}{cccccccc}
\hline $\begin{array}{c}\mathbf{A l}_{2} \mathbf{O}_{3} \\
\text { content } \\
(\mathbf{x})\end{array}$ & $\begin{array}{c}\text { Crystallite } \\
\text { size }(\mathbf{n m})\end{array}$ & $\begin{array}{c}\text { Theoretical } \\
\text { Lattice } \\
\text { constant } \\
\left(\mathbf{A}^{\mathbf{0}}\right)\end{array}$ & $\begin{array}{c}\text { Experimental } \\
\text { Lattice } \\
\text { constant }\left(\mathbf{A}^{\mathbf{0}}\right)\end{array}$ & $\begin{array}{c}\mathbf{X}-\text { Ray } \\
\mathbf{d e n s i t y} \\
\mathbf{( g / \mathbf { c m } ^ { 3 } )} \\
* \mathbf{1 0}^{-23}\end{array}$ & $\begin{array}{c}\text { d-spacing } \\
(\mathbf{A})\end{array}$ & $\begin{array}{c}\text { Surface } \\
\text { area }(\mathbf{n m})\end{array}$ & $\begin{array}{c}\text { Strain } \\
(\boldsymbol{\varepsilon})\end{array}$ \\
\hline 0.0 & 24.67 & 8.4258 & 8.4260 & 2.02371141 & 2.54050 & 1201.80 & 0.50910 \\
0.2 & 30.00 & 8.3950 & 8.3950 & 2.04601266 & 2.53120 & 9775.11 & 0.31301 \\
0.5 & 32.9 & 8.360 & 8.3610 & 2.07128244 & 2.52090 & 8804.73 & 0.23370 \\
0.8 & 30.85 & 8.360614 & 8.360 & 3.10829593 & 2.52082 & 6256.44 & 0.24905 \\
\hline
\end{tabular}

Scanning and transmission electron microscopy (HRSEM /HRTEM)

HR-SEM images revealed that aggregate nanostructures with spherical shapes and particle sizes in nano-scales are bonded in the prepared nano-ferrites (Fig. 2a-c). From the HR-SEM images, it is clear that the surface morphology of these samples shows dense nanostructure particles assembly of fine nanoparticles and agglomerated as non-uniform sheets for the $\mathrm{Ni}_{0.5}$ $\mathrm{Zn}_{0.5} \mathrm{Fe}_{2} \mathrm{O}_{4}$ doped with $(0.1$ and 0.3$) \mathrm{Al}_{2} \mathrm{O}_{3}$ ions. Figure 2(B) appears the HR-TEM images for the prepared ferrite nano-particles, obtained at $800^{\circ} \mathrm{C}$. All samples reveal that the ferrite nanoparticles of nearly spherical shape and the size about 7-29 $\mathrm{nm}$ are uniformly distributed. For the doped 
samples with $(0.1,0.3) \mathrm{Al}_{2} \mathrm{O}_{3}$ ions, Fig. $2 \mathrm{~B}(\mathrm{~b}$, c) shows a denser distribution of nanoparticles and agglomeration. The established nanoparticles size from the HR-TEM images is agreement to the values evaluated from XRD results.
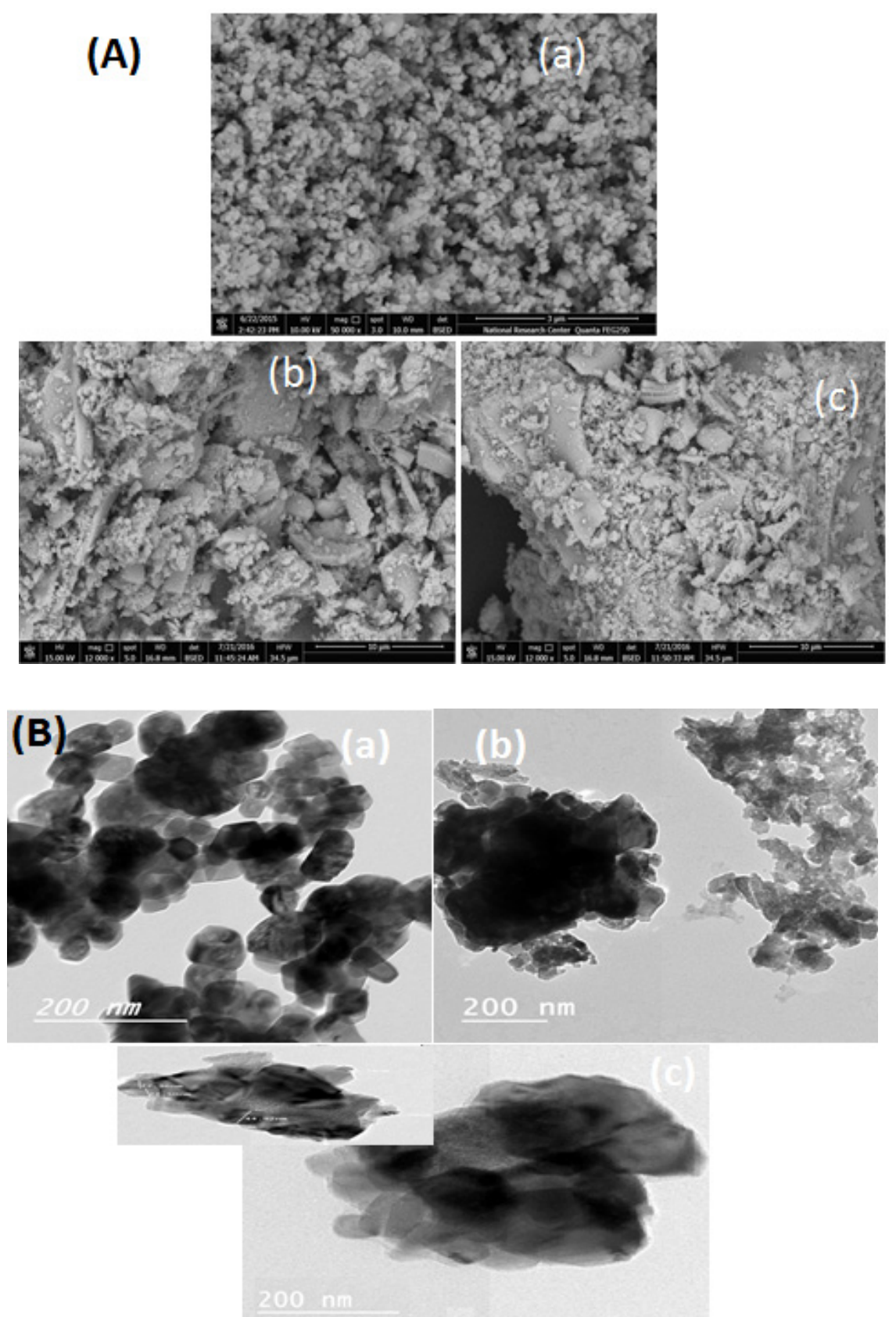

Fig. 2 (A, B). HR-SEM and HR-TEM images of $\mathrm{Al}_{\mathrm{x}} \mathrm{Ni}_{0.5}-\mathrm{xZn}_{0.5} \mathrm{Fe}_{2} \mathrm{O}_{4}(\mathrm{x}=0.0,0.1 \&$ 0.3) nano-crystalline calcined at $800^{\circ} \mathrm{C}$ for $3 \mathrm{~h}$.

\section{FTIR Analysis}

Figure 3, shows the FTIR spectra of spinel $\mathrm{Al}_{\mathrm{x}} \mathrm{Ni}_{0.5-\mathrm{x}} \mathrm{Zn}_{0.5} \mathrm{Fe}_{2} \mathrm{O}_{4}(\mathrm{x}=0.0,0.1,0.2 \& 0.3)$ nano particle prepared by citrate sol-gel method, in the rang $400-4000 \mathrm{~cm}^{-1}$. The observed FTIR peaks are at $3461 \mathrm{~cm}^{-1}$ and $2357 \mathrm{~cm}^{-1}$ assigned to stretching vibrations of $(\mathrm{O}-\mathrm{H})$ groups and stretching $(\mathrm{C}-\mathrm{H})$ respectively [22]. The sharp peak at $1621 \mathrm{~cm}^{-1}$ and
$1122 \mathrm{~cm}^{-1}$ is corresponding to stretching vibration of(M-O), which confirm the formation of the metaloxygen in ferrite-based. The absorption band at 1386 corresponding to the nitrates from which the $\mathrm{Ni}, \mathrm{Zn}$ and $\mathrm{Fe}$ functional groups and their linkages and disappeared with introducing the $\mathrm{Al}_{2} \mathrm{O}_{3}$ ions in $\mathrm{NiZnFe}_{2} \mathrm{O}_{4}[23]$. The spectra for the prepared samples give characteristic bands at $457 \mathrm{~cm}^{-1}$

Egypt.J.Chem. 62, No. 3 (2019) 
(metal ion- oxygen $\left(\mathrm{M}_{\text {octa }}-\mathrm{O}\right)$ at octahedral-site) and $605 \mathrm{~cm}^{-1}$ (metal ion- oxygen $\left(\mathrm{M}_{\text {tetra }}-\mathrm{O}\right)$ at tetrahedral-site), which are the significant bands of
$-\mathrm{Fe}_{2} \mathrm{O}_{4}$ groups, which is due to the formation of $\mathrm{NiZnFe}_{2} \mathrm{O}_{4}$ nano-structure [24].

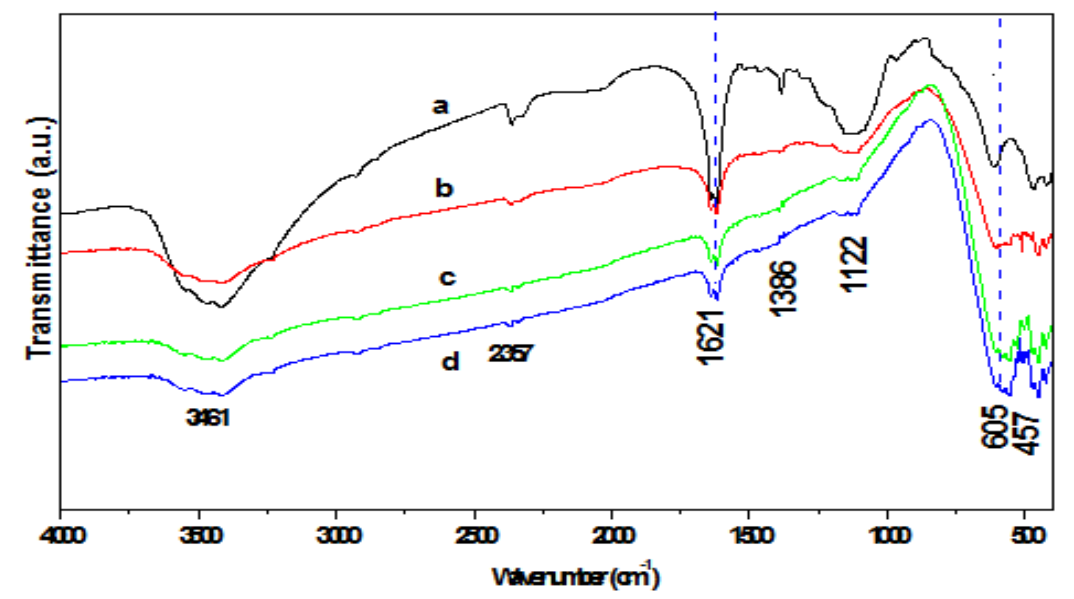

Fig. 3. FTIR spectra of $\mathrm{Al}_{x} \mathrm{Ni}_{0.5}-\mathrm{xZn}_{0.5} \mathrm{Fe}_{2} \mathrm{O}_{4}(\mathrm{x}=0.0,0.1,0.2 \&$ 0.3) nano-crystalline calcined at 800oC for $3 \mathrm{~h}$.

Magnetic studies

Magnetic measurements were done in room temperature of the $\mathrm{Al}_{\mathrm{x}} \mathrm{Ni}_{0.5-\mathrm{x}} \mathrm{Zn}_{0.5} \mathrm{Fe}_{2} \mathrm{O}_{4}(\mathrm{x}=0.0$, $0.1,0.2 \& 0.3)$ nano-crystalline showed typical magnetic behavior for the nano-ferritecalcined at $800^{\circ} \mathrm{C}$ for $3 \mathrm{~h}$, as observed in Fig. 4. The internal area for the M-H hysteresis loop illustrates amagnetic energy loss. This area for pure and doped $\mathrm{NiZnFe}_{2} \mathrm{O}_{4}$ is small which a particular feature for a soft ferrite. Different magnetic parameters as saturation magnetization (Ms), coercivity $(\mathrm{Hc})$ and remnant magnetization $(\mathrm{Mr})$ are specified of the room temperature hysteresis loop for various concentrations of $\mathrm{Al}^{2+}$ ions and are evaluated in Table 2. The observed changes in values of Ms, Hci and $\mathrm{Mr}$ with increasing of Al concentrations can be proved to the specific basis of exchange interactions between difference ions at tetrahedral (A) and octahedral (B) sites in ferrites [25].

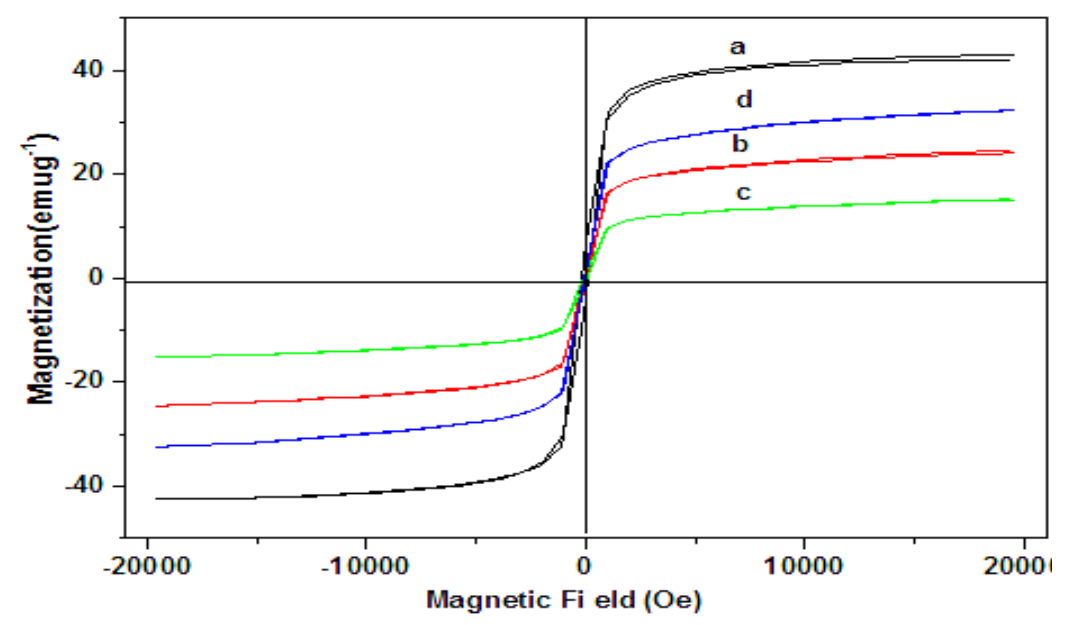

Fig. 4. Room temperature $\mathrm{M}-\mathrm{H}$ curves of $\mathrm{Al}_{\mathrm{x}} \mathrm{Ni}_{0.5-\mathrm{x}} \mathrm{Zn}_{0.5} \mathrm{Fe}_{2} \mathrm{O}_{4}(\mathrm{x}=\mathbf{0 . 0}, \mathbf{0 . 1}, 0.2$ \& 0.3$)$ nano-crystalline calcined at $800^{\circ} \mathrm{C}$ for $3 \mathrm{~h}$. 
TABLE 2. Values of Saturation magnetization (Ms), Remnant (Mr), Coercive field, Squarness for $\mathrm{Al}_{\mathrm{x}} \mathbf{N i}_{0.5-\mathrm{x}} \mathbf{Z n}_{0.5}$ $\mathrm{Fe}_{2} \mathrm{O}_{4}(x=0.0,0.1,0.2 \& 0.3)$ nano-crystalline

\begin{tabular}{lcccc}
\hline \multicolumn{1}{c}{ Sample } & $\mathbf{M}_{\mathbf{s}}(\mathbf{e m u} / \mathbf{g})$ & $\mathbf{M}_{\mathbf{r}}(\mathbf{e m u} / \mathbf{g})$ & $\mathbf{H}_{\mathbf{c i}}(\mathbf{G})$ & Squareness $(\mathbf{M r} / \mathbf{M s})$ \\
\hline $\mathrm{Ni}_{0.5} \mathrm{Zn}_{0.5} \mathrm{Fe}_{2} \mathrm{O}_{4}$ & 47.894 & 1.347 & 70.37 & $28.125 \mathrm{E}^{-3}$ \\
$\mathrm{Ni}_{0.4} \mathrm{Al}_{0.1} \mathrm{Zn0}_{5 .} \mathrm{Fe}_{2} \mathrm{O}_{4}$ & 15.194 & 1.1394 & 104.34 & $74.991 \mathrm{E}^{-3}$ \\
$\mathrm{Ni}_{0.3} \mathrm{Al}_{0.2} \mathrm{Zn0}_{.5} \mathrm{Fe}_{2} \mathrm{O}_{4}$ & 24.562 & 1.2568 & 69.226 & $51.166 \mathrm{E}^{-3}$ \\
$\mathrm{Ni}_{0.2} \mathrm{Al}_{0.3} \mathrm{Zn0}_{5.5} \mathrm{Fe}_{2} \mathrm{O}_{4}$ & 32.314 & 1.4133 & 60.117 & $43.735 \mathrm{E}^{-3}$ \\
\hline
\end{tabular}

Where, the replacement of nonmagnetic $\mathrm{Al}^{2+}$ ions with the magnetic $\mathrm{Ni}^{2+}$ ions changes the magnetization behavior of the octahedral site. The effect of Al-replacement is the gradual increase in the values of Ms, Hci and Mr. Also, the decrease in the $\mathrm{Ms}$ and $\mathrm{Mr}$ in the case of doped $\mathrm{Ni}_{0.5} \mathrm{Zn}_{0.5} \mathrm{Fe}_{2} \mathrm{O}_{4}$ may be due to the basis of canted spin or spin of the nonmagnetic Al cation at the surface of nanoferrites [26].

\section{Conclusion}

$\mathrm{Al}_{\mathrm{x}} \mathrm{Ni}_{0.5-\mathrm{x}} \mathrm{Zn}_{0.5} \mathrm{Fe}_{2} \mathrm{O}_{4}(\mathrm{x}=0.0,0.1,0.2,0.3)$ nanocrystalline were successfully prepared by the citrate sol-gel method and calcined at $800^{\circ} \mathrm{C}$. The formation of single phase cubic spinel structure was observed by X-ray diffraction powder. The obtained crystallite sizes of the prepared nanoferrites investigated by XRD line broadening was are in the range of 24-32 nm and in good agreement with HR-TEM analysis. The FT-IR spectra confirmed the successful formation of the metal oxide bonds in the prepared nano-ferrites. The saturation magnetization (Ms) and coercivity (Hc) values vary from 47.894-32.314 and 70.37$60.117 \mathrm{G}$; respectively. The decrease of $\mathrm{Ms}$ and Hci values with increasing the $\mathrm{Al}_{2} \mathrm{O}_{3}$ content due to the weakening of sub-lattice interactions from the nonmagnetic $\mathrm{Al}_{2} \mathrm{O}_{3}$ with the nano-ferrites which lowers the magnetic moment of the unit cell.

\section{Conflicts of Interest}

The authors declare no conflict of interest.

\section{References}

1. Kumar G., Shah J., Kotnala K. R., Singh P.V., Garg S. G., Shirsath E. S., Batoo M. K., Singh M., Superparamagnetic behaviour and evidence of weakening in super-exchange interactions with the substitution of $\mathrm{Gd} 3+$ ions in the Mg-Mn nanoferrite matrix, Mater. Res. Bull. 63, 216-225 (2015).

2. El nahrawy M. A., Ali I. A., Abou Hammad B. Egypt.J.Chem. 62, No. 3 (2019)
A., Mbarek A., Structural and optical properties of wet-chemistry $\mathrm{Cu}$ co-doped $\mathrm{ZnTiO} 3$ thin films deposited by spin coating method, Egyptian J. of Chemistry, 61, 770-780 (2018).

3. Rao P. B., Rao H. K., Asokana K., Caltunb F. O., Influence of titanium substitutions on the magnetic properties of Ni-Zn ferrites, J. of Optoelect. and Advanced Materials, 6, 959 - 962 (2004).

4. Raut V. A., Khirade P. P.,. Humbe A, Jadhav A. S., Shengule R. D., Structural, Electrical, Dielectric and Magnetic Properties of Al3+ Substituted NiZn Ferrite, J Supercond Nov Magn. 29, 13311337 (2016).

5. Gaffoor A., Ravinder D., Characterization of magnesium substituted nickel nano ferrites synthesized by citrate-gel auto combustion method, Eng Res Appl 4, 60-66 (2014).

6. Tholkappiyan R., Vishista K., Combustion synthesis of $\mathrm{Mg}-\mathrm{Er}$ ferrite nanoparticles: Cation distribution and structural, optical, and magnetic properties, Mater Sci Semicond Process. 40, 631642 (2015)

7. Kumar G., Shah J., Kotnala K. R., Singh P.V., Garg S.G., Shirsath E. S., Bato M. K., Singh M., Superparamagnetic behaviour and evidence of weakening in super-exchange interactions with the substitution of $\mathrm{Gd} 3+$ ions in the $\mathrm{Mg}-\mathrm{Mn}$ nanoferrite matrix, Mater. Res. Bull. 63, 216-225 (2015).

8. Goldman A., Modern Ferrite Technology, 2nd edn. Springer, Pittsburgh, 51-61 (2006).

9. Atif M., Nadeem M., Sol-gel synthesis of nanocrystalline $\mathrm{Zn1}-\mathrm{xNixFe} 2 \mathrm{O} 4$ ceramics and its structural, magnetic and dielectric properties, $J$. Sol-Gel Sci. Technol. 14, 3484-3488 (2014).

10. Morriso A. S., Cahill L. C., Carpenter E. E., Calvin S., Swaminathan R., McHenry E. M., Harris G V., Magnetic and structural properties of nickel zinc ferrite nanoparticles synthesized at 
room temperature, J. of Applied Phys. 95, 63926398 (2004)

11. Knobel M., Os superpoderes dos nanomagnetos. Ciência Hoje 159, 33-37 (2000).

12. Shrotri J. J., Kulkarni D. S., Deshpande E. C., Mitra A., Sainkar S. R., Anil Kumar S. P., Date K. S., Effect of $\mathrm{Cu}$ substitution on the magnetic and electrical properties of $\mathrm{Ni}-\mathrm{Zn}$ ferrite synthesized by soft chemical method, Mater. Chem. Phys. 59, 1-5 (1999).

13. Moghsoudi I., Shokrollahi H., Hadianfard J. M, Amighian J., Synthesis and characterization of NiAlxFe2 - xO4 magnetic spinel ferrites produced by conventional method Powder Technol, Powder Technol. 235, 110-114 (2013).

14. Bhukal S., Namgyal T., Mor S., Bansal S., Singhal S., Structural, electrical, optical and magnetic properties of chromium substituted $\mathrm{Co}-\mathrm{Zn}$ nanoferrites $\mathrm{Co} 0.6 \mathrm{Zn} 0.4 \mathrm{CrxFe} 2$ xO4 (0 6 x 6 1.0) prepared via sol-gel auto-combustion method, $J$. of Molec. Struct. 1012, 162-167 (2012).

15. Lin Leng P., Saion E., Naseri G. M., Mehdipour A. L., Shaari H. A., Kamaruddin M.A., A simple thermal treatment synthesis and characterization of Ni-Zn Ferrite (Ni0.5Zn0.5Fe2O4) nanocrystals, J. of Applied Physics (IOSR-JAP), 4, 30-36 (2013).

16. Sileo E. E., Rotelo R., Jacobo E. S., Nickelzinc ferrites prepared by the citrate precursor method, Journal of Electromagnetic Analysis and Applications, Physical: B, 320, 257-260 (2002).

17. Babu B. R., Prasad R. S. M., Ramesh V. K., Effect on structural and magnetic properties of aluminum substituted Ni-Zn Nano ferrite system prepared via citrate-gel route, Int. J. Mod. Phys. B 29, 1550032-1550044 (2015).

18. Al-Qubaisi S. M., Rasedee A., Flaifel H. M., Ahmad H. S., S. H. Al-Ali, Hussein Z. M., Eid
E. E., Zainal Z., Saeed M., Ilowefah M., The nanohybrid is of mesopores type with $58.8 \%$ drug loading and enhanced thermal stability, Int $J$ Nanomedicine, 8, 2497-2508 (2013).

19. Adriana A. S., Jose A. D., Waldermar M. A. A., Nanosized powders of NiZn ferrite: Synthesis, structure, and magnetism, J. Appl. Phy. 87. 4352 -4357 (2000).

20. Prabhu1 T. Y., Rao V. K., Kumar S. S. V., Kumari S. B., X-Ray analysis by Williamson-Hall and size-strain plot methods of $\mathrm{ZnO}$ nanoparticles with fuel variation, Nano Sci Eng. 4, 21-28 (2014).

21. Kingery D. W., Bowen K. H., Uhlmann R. D., Introduction to Ceramics, 2nd edn. Wiley, New York, p 131 (1976).

22. Naik S., Parveez A., Chaudhuri A., Abdul Khader S., Structural, dielectric and electrical properties of $\mathrm{Ni}(\mathrm{Cd}, \mathrm{Zn}) \mathrm{Fe} 2 \mathrm{O} 4$ by Auto Combustion method, Materials Today: Proceed. 4, 1210312108 (2017).

23. Braber M. A. V., Infrared Spectra of Cubic and Tetragonal Manganese Ferrites, Physics. Status Solidi 33, 563 (1969).

24. Socrates G., Infrared and Raman Characteristic Group Frequencies, John Wiley and Sons, New York (2001).

25. Deraz M. N., Effects of magnesia addition on structural, morphological and magnetic properties of nanocrystalline nickel ferrite system, Ceram. Int. 38, 511-516 (2012).

26. Obaidat M. I., Issa B., Haik Y., Magnetic properties of magnetic nanoparticles for efficient hyperthermia, Nanomater. Nanotechno. 5, 63-89 (2015).

(Received 25/7/2018; accepted 17/10/2018) 


\section{الخواص التركيبية والمغناطيسية للنيكل زنتك فريت المطعمة جسيمات الالومنيوم النانومترية و المحضرة بطريقة السائل الجيلاتينى المبلئي

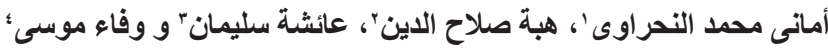

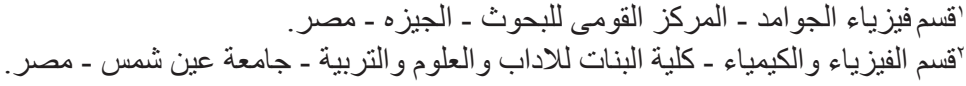

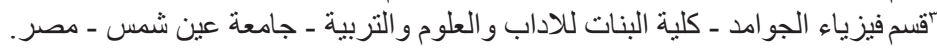

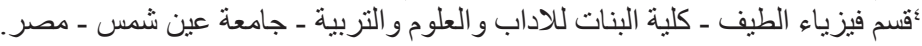

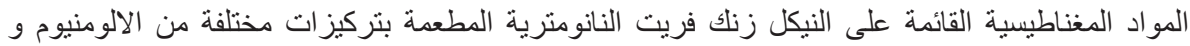

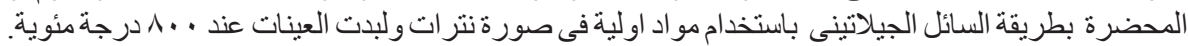

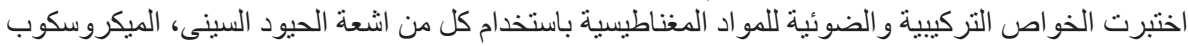

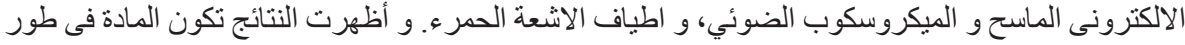

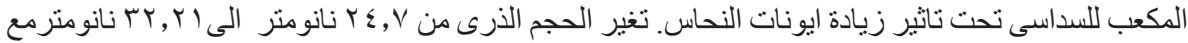

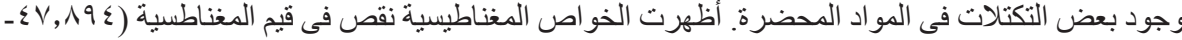

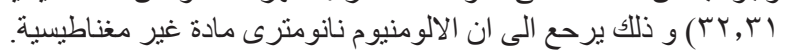

